\title{
Znaczenie warunków geologicznych i geomorfologicznych dla rozwoju i współczesnego stanu torfowisk Niecki Nidziańskiej
}

\author{
Daniel Okupny ${ }^{1,2}$, Witold Jucha ${ }^{1}$
}

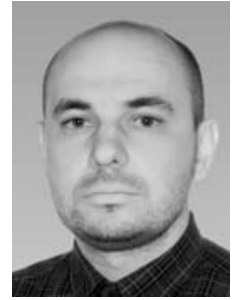

D. Okupny

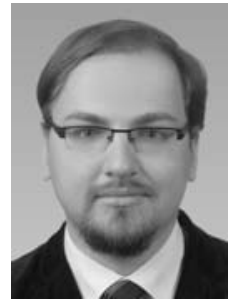

W. Jucha

Significance of geological and geomorphological conditions for development and the contemporary state of peatlands in the Nida Basin. Prz. Geol., 68: 135-144; doi: 10.7306/2020.6

A b s tr a c t. Synthetic studies of biogenic deposits made on a regional scale reveal how the geological structure and land relief have been affecting the development of limnic and peat sediments. The research was made in the Nida Basin, which is the region of great diversity of natural landscape in southern Poland and has a relatively large area of peatlands. The conclusions have been based on SRTM interpretation, hydrogeological documentations of deposits near Busko-Zdrój, and field and laboratory works. The spring-fed fen at Zwierzyniec, along with the fen at Mikutowice, has been forming on the densest complexes of alkaline fens in the Matopolska Upland. The calcareous tufa includes records of chemical denudation occurring in the southern part of the Pińczów Hump in the Late Weichselian and Holocene.

Keywords: biogenic deposits, geomorphometry, peatland, spring-fed fen, Nida Basin

Wzrost zainteresowania mokradłami, wyraźnie zauważalny w ostatnich latach, wynika $\mathrm{z}$ funkcji, jakie te ekosystemy pełnią w środowisku. $Z$ jednej strony torfowiska są siedliskami zwiększającymi różnorodność krajobrazową i biologiczną (Łachacz, 2004), z drugiej zaś pełnią ważną rolę w obiegu wody oraz akumulacji martwej materii organicznej (Gorham, 1991; Waddington, Price, 2000). Z tego też powodu wszelkie działania z zakresu ochrony środowiska powinny uwzględniać ilościową i jakościową ocenę stanu torfowisk, w tym z wykorzystaniem wielu wskaźników (multi-proxy) stanowiących współcześnie trzon badań paleoekologicznych (Lamentowicz, 2007). Na uwagę zasługuje szeroko rozumiany monitoring funkcjonowania mokradeł torfotwórczych, zwłaszcza w kontekście negatywnych zmian szybko postępujących w ich obrębie. Do zmian tych należą: zaburzenia uwarunkowań hydrogeochemicznych, zmniejszanie zasięgu tych obiektów, ich fragmentacja, a nawet całkowity zanik (Barber, 1993; Łajczak, 2013; Marcisz i in., 2014; Solovey, Jóźwiak, 2019). Zmiany poziomu wody gruntowej i powierzchniowej, zapisane w seriach sukcesyjnych torfowisk, dowodza, że proces zatorfienia rozpoczęty w późnym glacjale był ściśle związany $\mathrm{z}$ warunkami hydrogeologicznymi oraz rzeźbą terenu (Żurek, 1991/1992; Forysiak, 2012). Istotną rolę w badaniach współczesnych zbiorników akumulacji biogenicznej pełni kryterium geologiczne (Tobolski, 2004). Składają się na nie m.in.: badania nad oceną wpływu litologii podłoża, rzeźby terenu i zasilania na rozwój torfowisk. Szczególne pod tym względem są torfowiska źródliskowe, których rozwój jest związany ze stałym zasilaniem wodami podziemnymi o podwyższonej twardości, zasobnymi w węglan wapnia (Dobrowolski, 2011; Dobrowolski i in., 2019). Tematyka torfowisk źródliskowych na Wyżynie Małopolskiej, dobrze rozpoznanej pod względem hydrogeologicznym, była bardzo rzadko poruszana (Ławrynowicz, 1977; Przemyski, Wołejko, 2011), w przeciwieństwie do pozo- stałej części krasowych wyżyn węglanowych (Alexandrowicz i in., 1994; Dobrowolski, 1994; Pazdur i in., 2002; Dobrowolski i in., 2002) czy Niżu Polskiego (Alexandrowicz, Żurek, 1996; Wołejko, 2002; Ziułkiewicz i in., 2012; Mazurek i in., 2014). Tymczasem podobne torfowiska źródliskowe występują w Niecce Nidziańskiej, w strefie od Buska-Zdroju po Pińczów, gdzie Okupny i in. (2018) przedstawili liczne przykłady występowania sekwencji rytmicznie warstwowanych osadów biogenicznych (torfów) oraz węglanowych (martwic wapiennych). Usytuowanie geomorfologiczne oraz litologia tych osadów są typowe dla torfowisk źródliskowych wiszących, rzadziej tworzą one kopuly torfowo-martwicowe.

Celem artykułu jest ukazanie związku rozwoju torfowisk Niecki Nidziańskiej z jej budową geologiczną i rzeźbą. Region ten cechuje czterokrotnie większy wskaźnik zatorfienia od pozostałej części Wyżyn Polskich. W pracy przedstawiono dotychczasowy stan rozpoznania osadów wybranych mokradeł torfotwórczych niecki, w tym także wstępne wyniki badań kilku nowo udokumentowanych stanowisk torfowisk źródliskowych. Tym samym artykuł wpisuje się w nurt badań nad węglanowymi (alkalicznymi) torfowiskami typu niskiego, których udział w powierzchni wszystkich torfowisk w kraju nie przekracza 1\% (Jasnowski, 1975).

\section{OBSZAR BADAŃ}

Niecka Nidziańska leży w środkowej części Wyżyny Małopolskiej (Solon i in., 2018) i stanowi wyraźne obniżenie względem sąsiednich obszarów Wyżyny Krakowsko-Częstochowskiej i Wyżyny Kielecko-Sandomierskiej (ryc. 1). Zgodnie z podziałem geomorfologicznym Niecki Nidziańskiej przyjętym przez Cabaja i Nowaka (1986) w skład badanego regionu wchodzi 13 jednostek, spośród których największą powierzchnię ma Niecka Włoszczowska, najmniejszą zaś Dolina Nidy (ryc. 1). Wśród nich jedynie

\footnotetext{
${ }^{1}$ Wydział Nauk Ścisłych i Przyrodniczych, Uniwersytet Pedagogiczny im. KEN, ul. Podchorązych 2, 30-084 Kraków

${ }^{2}$ Wydział Nauk Ścisłych i Przyrodniczych, Uniwersytet Szczeciński, ul. Adama Mickiewicza 16, 70-383 Szczecin; daniel.okupny@usz.edu.pl
} 


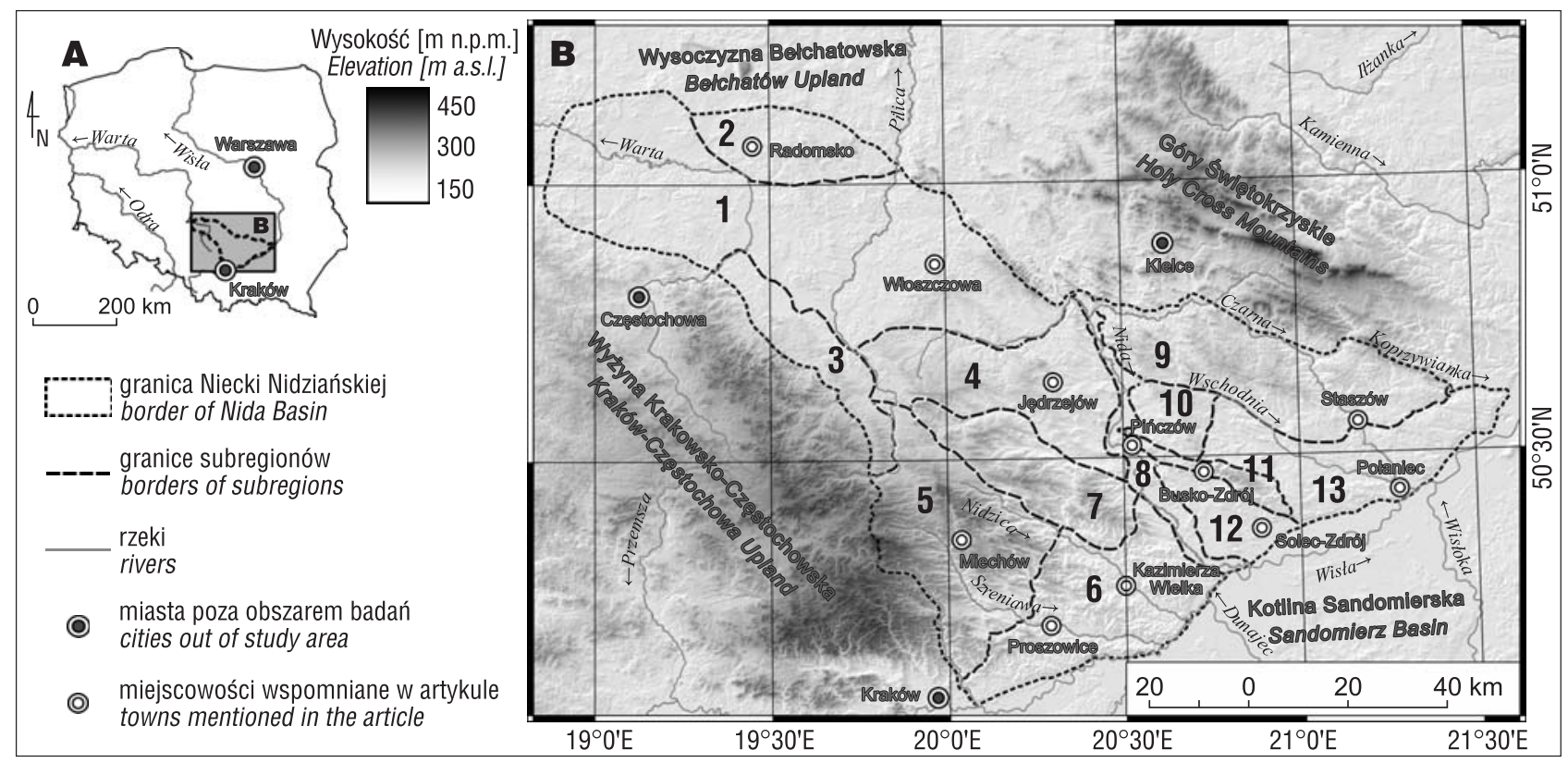

Ryc. 1. Lokalizacja obszaru badań i podział na subregiony geomorfologiczne wg Cabaja i Nowaka (1986): 1 - Niecka Włoszczowska, 2 - Wzgórza Radomszczańskie, 3 - Próg Lelowski, 4 - Płaskowyż Jędrzejowski, 5-Wyżyna Miechowska, 6 - Działy Proszowickie, 7 - Garb Wodzisławski, 8 - Dolina Nidy, 9 - Płaskowyż Szydłowski, 10 - Płaskowyż Szaniecki, 11 - Garb Pińczowski, 12 - Niecka Solecka, 13 - Niecka Połaniecka

Fig. 1. Location of the study area against the geomorphic subregions by Cabaj and Nowak (1986)

na Płaskowyżu Szanieckim i w Niecce Soleckiej dominuje rzeźba strukturalno-denudacyjna rozwinięta na utworach mioceńskich oraz kredowych (tab. 1). W pozostałych jednostkach udział rzeźby akumulacyjnej i denudacyjno-erozyjnej rozwiniętej na utworach czwartorzędowych przekracza 50\% powierzchni, a na obszarze Wzgórz Radomszczańskich, Działów Proszowickich oraz Doliny Nidy (ryc. 1) dochodzi nawet do 90\%.

Nieco mniej niż połowę powierzchni Niecki Nidziańskiej zajmuje dorzecze Nidy (47\%), pozostały obszar jest odwadniany głównie przez rzeki: Dłubnię, Szreniawę, Nidzicę, Koprzywiankę, Wschodnią, Czarną oraz górne odcinki Warty i Pilicy. Na przeważającym obszarze zwierciadło wód podziemnych zalega stosunkowo głęboko (nawet 100 m p.p.t.), wydajność licznych źródeł zależy zaś od miąższości i przepuszczalności skał tworzących warstwy wodonośne. Lokalnym zgrupowaniom wydajnych wypływów wód podziemnych (nawet powyżej $50 \mathrm{l}$ /s) sprzyja występowanie uskoków (Chełmicki, 1986). Na zróżnicowany skład chemiczny wód podziemnych tego obszaru istotny wpływ ma jego struktura blokowo-fałdowa (system uskoków o zróżnicowanym zasięgu i orientacji przestrzennej) oraz poziomy wodonośne związane $z$ utworami czwartorzędu, neogenu, kredy i lokalnie jury (Wicik, 2000a; Jóźwiak, Różkowski, 2015).

Obecnie na terenie Niecki Nidziańskiej prowadzi się eksploatację wód leczniczych typu: Cl-Na, S, I oraz Cl-Na, I, które łącznie z wydobyciem mułów borowinowych (torfów nasyconych związkami siarki), stały się podstawą działalności uzdrowisk w Busku-Zdroju i Solcu-Zdroju (Herman, Gagol, 2000; Prażak, 2012). Z obliczeń Żurka (1981) wynika, że eksploatacją torfu w środkowej części Wyżyny Małopolskiej objęto 30\% torfowisk, a obszar wyrobisk poeksploatacyjnych dochodzi do 7\% ogólnej powierzchni wszystkich obszarów podmokłych. Najważniejszymi złożami torfu i gytii, przeznaczonymi do lecznictwa uzdrowiskowego i eksploatowanymi na skalę przemysłową, są na terenie Niecki Nidziańskiej: Miku-
łowice-Siwice, Szaniec-Wymysłów, Skorzów, Kobylniki oraz Stopnica-Kargów-Sufczyce (Karski, 1971; Gałka i in., 2006). Niektóre duże torfowiska (np. w Pierzchnicy), zostały wyeksploatowane prawie całkowicie. Mimo wyraźnych zmian w środowisku przyrodniczym torfowisk Niecki Nidziańskiej, przetrwało na nich wiele rzadkich gatunków roślin oraz kilka zbiorowisk roślinnych (Głazek, 1989, 1992; Towpasz, Stachurska-Swakoń, 2009; Przemyski, Wołejko, 2011).

\section{MATERIAL I METODY BADAŃ}

Do scharakteryzowania torfowisk wykorzystano dane ze wstępnych dokumentacji złożowych, zestawionych przez Piwockiego (1971) oraz Żurka (1981). Warunki geologiczne i genezę rzeźby rozpoznano na podstawie literatury przedmiotu (Łyczewska, 1975; Rutkowski, 1981, 1986; Lindner, 1984; Cabaj, Nowak, 1986; Urban, 2014) oraz analizy opracowań geologicznych dotyczących ujęć wody podziemnej w okolicach Buska-Zdroju (Marszałek, 1970; Siemieniec, 2002). Ponadto z 30 arkuszy Szczegółowej Mapy Geologicznej Polski (SMGP) w skali 1 : 50000 przeniesiono zasięgi dwóch wydzieleń litologicznych odnoszących się do osadów biogenicznych (torfów oraz torfów na innych osadach).

Parametry morfometryczne pozyskano w środowisku GIS, wykorzystując do tego celu programy Quantum GIS i GRASS GIS oraz materiały przestrzenne - mapy i modele wysokościowe. Analizę zróżnicowania rzeźby terenu w poszczególnych jednostkach Niecki Nidziańskiej oparto na badaniu rozkładu dwóch parametrów, pochodnych $\mathrm{z}$ cyfrowego modelu wysokościowego (analiza numerycznych modeli terenu): nachylenia terenu oraz wskaźnika wilgotności gruntu (Topographic Wettness Index - TWI). Wskaźniki te umożliwiają wyznaczenie stref występowania potencjalnych obszarów podmokłych (Migoń, Kasprzak, 2014). Oba wskaźniki wygenerowano na podstawie cyfrowego modelu wysokościowego SRTM 
(https://www2.jpl.nasa.gov/srtm/) i zbadano z zastosowaniem narzędzi statystyk rastra w podziale na poszczególne jednostki subregionalne Niecki Nidziańskiej. Dane cyfrowe wykorzystano zgodnie z licencją wydaną przez Wojewódzki Ośrodek Dokumentacji Geodezyjnej i Kartograficznej dla Instytutu Geografii UP w Krakowie. Zgodę na skorzystanie $\mathrm{z}$ danych wysokościowych ALS ISOK, potrzebnych do zobrazowania niektórych obiektów, wydał Centralny Ośrodek Dokumentacji Geodezyjnej i Kartograficznej.

W ramach prac terenowych określono skład fizykochemiczny wód podziemnych wypływających we wsi Zwierzyniec z krawędzi niszy podcinającej południowe zbocze Garbu Pińczowskiego. Odczyn wody podziemnej pomierzono za pomocą miernika CP-401 firmy Elmetron, a twardość ogólną oznaczono fotometrem LF300 firmy Slandi. W Bełku, Sędowicach oraz Zwierzyńcu-Mikułowicach przeprowadzono kartowanie geologiczne torfowisk źródliskowych. Z użyciem laski holenderskiej wykonano 200 wierceń, a za pomocą próbnika Instorf pobrano 8 rdzeni osadów torfowo-martwicowych $\mathrm{z}$ różnych części torfowisk w Bełku, Sędowicach i Zwierzyńcu. Ze względu na specyfikę środowiska depozycyjnego torfowisk źródliskowych w opisie ich litologii uwzględniono sugestie metodyczne Dobrowolskiego (2011).

Podstawowe składniki litogeochemiczne pobranych osadów oznaczono w Laboratorium Geochemicznym Instytutu Nauk o Morzu Uniwersytetu Szczecińskiego: materię organiczną (metodą strat prażenia w piecu muflowym w temperaturze $550^{\circ} \mathrm{C}$ ) oraz węglan wapnia $-\mathrm{CaCO}_{3}$ (metodą objętościową przy użyciu aparatu Scheiblera). Opis rdzenia pobranego z torfowiska w Zwierzyńcu, oznaczonego jako Z-I, i jego makroskopową analizę litofacjalną wykonano zgodnie z założeniami niegenetycznej klasyfikacji osadów Troels-Smitha (Tobolski, 2000), uwzględniając modyfikację Dobrowolskiego (2011).

\section{ROZWÓJ TORFOWISK NA TLE WARUNKÓW GEOLOGICZNYCH I GEOMORFOLOGICZNYCH}

Charakterystyczną cechą Niecki Nidziańskiej jest zróżnicowanie rzeźby terenu, wynikające m.in. z litologii osadów oraz uwarunkowań morfogenetycznych, zarówno endo-, jak i egzogenicznych (Flis, 1954; Cabaj, Nowak, 1986; Urban, 2012). W granicach obszaru badań wydzielono cztery typy litologiczne rzeźby wyżynnej, tj. krzemionkowy, skał krasowiejących, lessowy i aluwialny (Janicki $\mathrm{i}$ in., 2008), jednak mimo to ukształtowanie terenu charakteryzuje się bardzo dużym udziałem powierzchni o niewielkim nachyleniu, najczęściej 2-4 (ryc. 2A, C). Większym udziałem obszarów o większych nachyleniach $\left(5-7^{\circ}\right)$ charakteryzują się Wyżyna Miechowska, Działy Proszowickie, Garb Wodzisławski oraz Garb Pińczowski (ryc. 1). Wartości wskaźnika TWI, wyliczone dla tych subregionów, są w związku z tym niższe - średnio o dwie jednostki (ryc. 2B, D). Najlepsze warunki morfologiczne do rozwoju torfowisk, wyrażone przez wskaźnik TWI, udokumentowano w Niecce Włoszczowskiej, na Płaskowyżu Jędrzejowskim i w Dolinie Nidy (ryc. 1). W tych trzech subregionach licznie występują kompleksy wydmowe z zagłębieniami bezodpływowymi, których udział w powierzchni wynosi nawet 8\% (Cabaj, Nowak, 1986).

Wymienione lokalne uwarunkowania geologiczne i geomorfologiczne obszaru badań znajdują odzwierciedlenie w szczególnym rozmieszczeniu i typie torfowisk, determinującym największe jego zatorfienie (ok. 4\%) w porównaniu do pozostałej części wyżyn południowopolskich, gdzie ich udział nie przekracza 1\% (Żurek, 1987, 2000). Zatorfienie Niecki Nidziańskiej jest jednak mocno zróżnicowane w poszczególnych subregionach. Wzrasta ono z południa w kierunku północnym i zachodnim. W Niecce Włoszczowskiej zatorfienie wynosi 8\%, w Dolinie Nidy, na

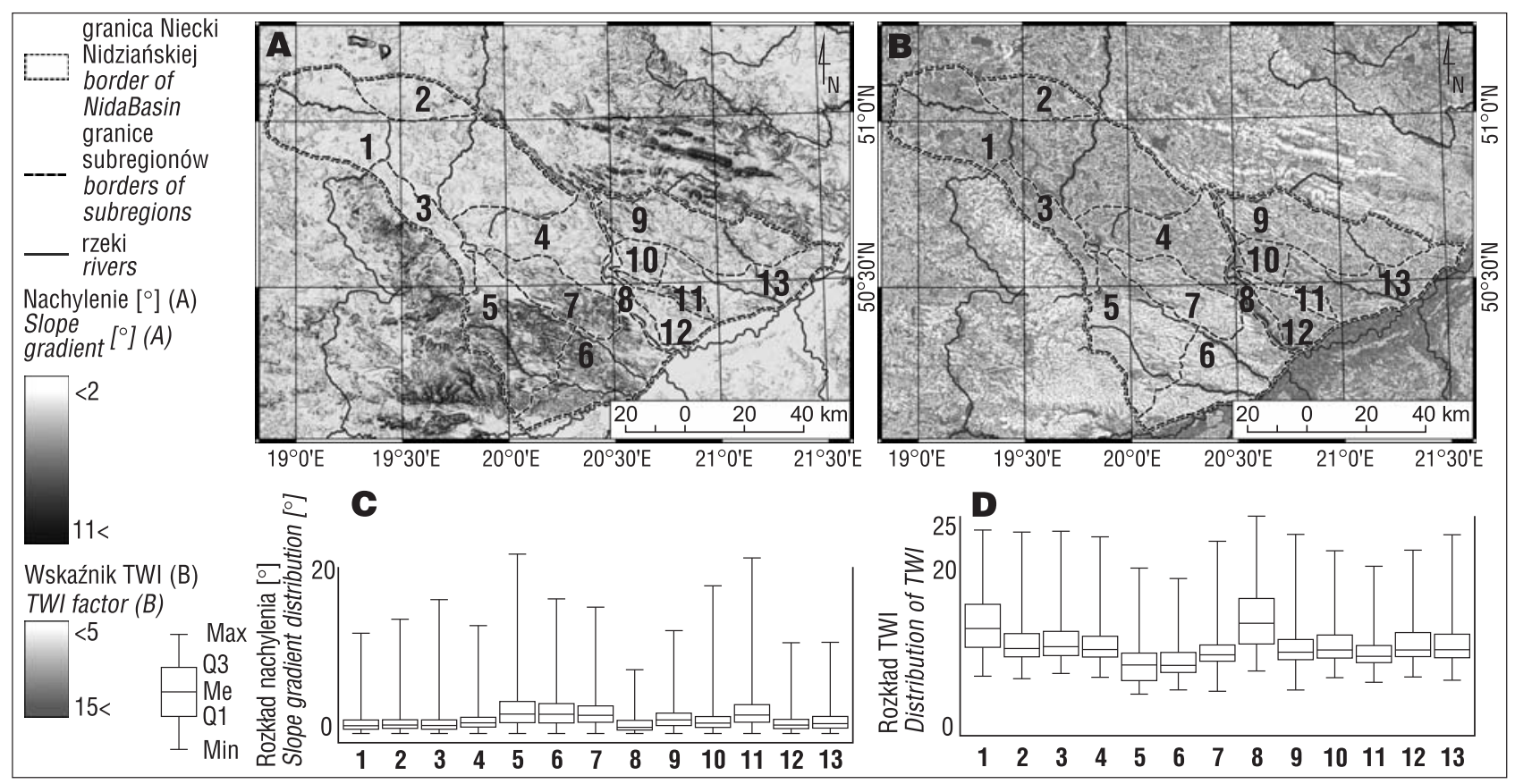

Ryc. 2. Mapa i rozkład nachyleń (A i C) oraz przestrzenne zróżnicowanie i rozkład topograficznego wskaźnika wilgotności (B i D) w subregionach geomorfologicznych Niecki Nidziańskiej wyróżnionych przez Cabaja i Nowaka (1986). Numery i nazwy subregionów jak na ryc. 1

Fig. 2. Map and distribution of the slope gradients (A and C), and spatial distribution of Topographic Wetness Index (B and $\mathbf{D})$ in the geomorphic subregions of the Nida Basin distinguished by Cabaj and Nowak (1986). Numbers and names of subregions as in Fig. 1 


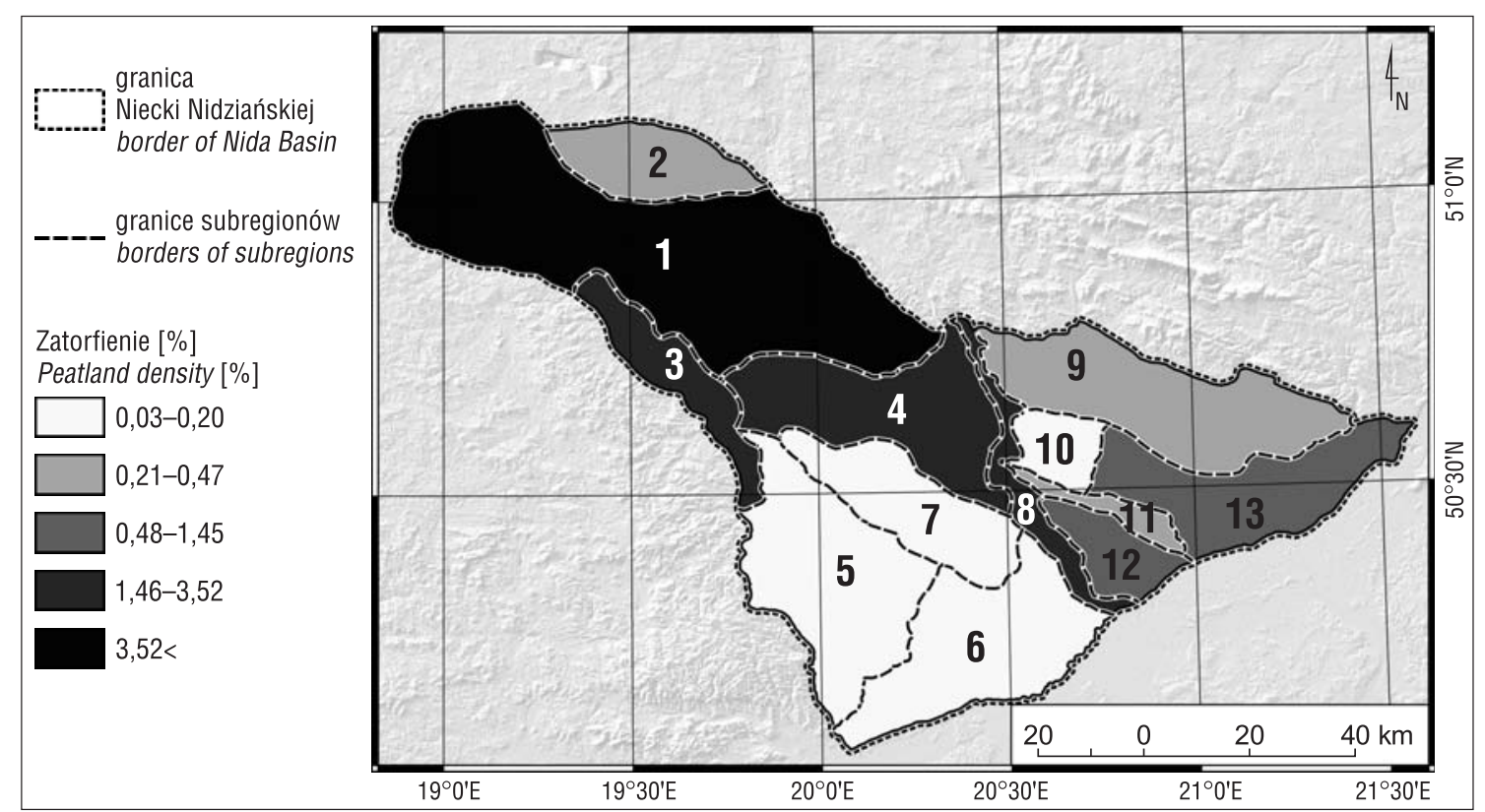

Ryc. 3. Zatorfienie Niecki Nidziańskiej wg subregionów fizycznogeograficznych wydzielonych przez Cabaja i Nowaka (1986). Numery i nazwy subregionów w objaśnieniach do ryc. 1

Fig. 3. Peatland density in the geomorphic subregions of the Nida Basin, distinguished by Cabaj and Nowak (1986). Numbers and names of subregions as in Fig. 1

Płaskowyżu Jędrzejowskim oraz Płaskowyżu Lelowskim waha się między 2,5 a 3,5\%, natomiast na Wyżynie Miechowskiej i w Działach Proszowickich wynosi mniej niż 0,05\% (ryc. 3). Spośród 360 torfowisk udokumentowanych na arkuszach Szczegółowej Mapy Geologicznej Polski Niecka Włoszczowska grupuje ich aż 160, natomiast Działy Proszowickie i Wyżyna Miechowska - tylko po 7 (tab. 1). Nieco inaczej wygląda sytuacja pod względem powierzchni torfowisk - w Niecce Włoszczowskiej, na Płaskowyżu Jędrzejowskim oraz Progu Lelowskim zaj- mują one odpowiednio 21 tys. ha; 3,5 tys. ha oraz 900 ha; na Wyżynie Miechowskiej - 29 ha, a na Płaskowyżu Szanieckim - zaledwie 22 ha. Wśród analizowanych cech ilościowych zróżnicowanie wykazuje także średnia powierzchnia torfowisk. Na Płaskowyżu Szanieckim oraz w Działach Proszowickich wynosi ona zaledwie 2 ha, w Dolinie Nidy, Niecce Połanieckiej oraz na Progu Lelowskim oscyluje wokół 35 ha, natomiast w Niecce Włoszczowskiej osiąga aż 132 ha. Powierzchnia 69\% torfowisk Płaskowyżu Szanieckiego oraz Działów Proszowickich jest mniejsza od 5 ha,

Tabela 1. Procentowy udział różnych typów rzeźby (wg Cabaja, Nowaka, 1981) oraz liczba i powierzchnia torfowisk (wg Piwockiego, 1971; Żurek, 1981 - zmienione) w subregionach Niecki Nidziańskiej

Table 1. Percentage of relief types of areas (after Cabaj, Nowak, 1981), number and area of peatlands (after Piwocki, 1971; Żurek, 1981 - changed) in particular subregions of the Nida Basin

\begin{tabular}{|c|c|c|c|c|c|}
\hline \multirow{2}{*}{$\begin{array}{l}\text { Subregion } \\
\text { Subregion }\end{array}$} & \multicolumn{2}{|c|}{$\begin{array}{l}\text { Rzeźba strukturalno-denudacyjna } \\
\text { w utworach: } \\
\text { Structural-denudational relief in: }\end{array}$} & \multirow{2}{*}{$\begin{array}{c}\text { Rzeźba akumulacyjna } \\
\text { i denudacyjno-erozyjna } \\
\text { w utworach czwartorzędowych } \\
\text { Accumulation and } \\
\text { denudational-erosional relief } \\
\text { in Quaternary deposits } \\
{[\%]}\end{array}$} & \multirow{2}{*}{$\begin{array}{c}\text { Liczba } \\
\text { torfowisk } \\
\text { Number of } \\
\text { peatlands }\end{array}$} & \multirow{2}{*}{$\begin{array}{c}\text { Powierzchnia } \\
\text { torfowisk } \\
\text { Peatland area } \\
\text { [ha] }\end{array}$} \\
\hline & $\begin{array}{c}\text { kredowych } \\
\text { i starszych } \\
\text { Cretaceous and } \\
\text { older deposits [\%] }\end{array}$ & $\begin{array}{c}\text { mioceńskich } \\
\text { Miocene deposits } \\
{[\%]}\end{array}$ & & & \\
\hline Niecka Włoszczowska & 14 & - & 86 & 160 & 21252 \\
\hline Wzgórza Radomszczańskie & 8 & - & 92 & 4 & 142 \\
\hline Próg Lelowski & 28 & - & 72 & 27 & 900 \\
\hline Płaskowyż Jędrzejowski & 48 & - & 52 & 53 & 3553 \\
\hline Wyżyna Miechowska & 21 & 1 & 78 & 7 & 29 \\
\hline Działy Proszowickie & 1 & 3 & 96 & 7 & 15 \\
\hline Garb Wodzisławski & 27 & - & 73 & 9 & 104 \\
\hline Dolina Nidy & 10 & - & 90 & 17 & 593 \\
\hline Płaskowyż Szydłowski & 24 & 9 & 67 & 14 & 304 \\
\hline Płaskowyż Szaniecki & 12 & 45 & 43 & 11 & 22 \\
\hline Garb Pińczowski & 16 & 20 & 64 & 8 & 52 \\
\hline Niecka Solecka & 10 & 41 & 49 & 17 & 302 \\
\hline Niecka Połaniecka & - & 19 & 81 & 26 & 890 \\
\hline
\end{tabular}


podczas gdy powierzchnia 15\% torfowisk Niecki Włoszczowskiej nawet pięciokrotnie przekracza 100 ha.

W starszym podłożu, które odsłania się na powierzchni zaledwie $25 \%$ regionu, wyróżniono skały górnokredowe i mioceńskie (Cabaj, Nowak, 1986). W wyniku denudacji chemicznej na obszarze Niecki Nidziańskiej rozwinęły się liczne formy krasu powierzchniowego i podziemnego, w tym m.in. zapadliska (leje) krasowe (Urban i in., 2015). Powstałe w ich obrębie zbiorniki akumulacji biogenicznej nie zapewniały jednak ciagłości przyrostu osadów jeziornych i torfowych, gdyż były silnie uzależnione od zasilania wodami gruntowymi. W gipsowym krajobrazie Niecki Nidziańskiej torfowiska stanowią zazwyczaj niewielkie powierzchniowo zbiorniki (do 10 ha) o maksymalnej miąższości osadów do $2 \mathrm{~m}$. Zdaniem Wicika (2000b) te torfotwórcze mokradła powstały w miejscach wypływu wód podziemnych o słabym ciśnieniu hydrostatycznym. Pod względem litologii i wieku osadów biogenicznych najciekawszymi obiektami tego typu są torfowiska: Aleksandrów, Gacki, Gaik-Winiary, Owczary i Żydowiec (ryc. 4).

W profilu torfowiska Parszywe Błonia w Aleksandrowie, które zajmuje dno obniżenia krasowo-denudacyjnego otoczonego wychodniami margli kredowych i gipsów, występuje w spagu cienka warstwa (ok. 0,5 m) murszów torfiastych, których najstarsze daty ${ }^{14} \mathrm{C}$ wynoszą $13910 \pm 100$ lat BP oraz $10370 \pm 150$ lat BP (Wicik, 2000b). Wicik (2000b) dokonał także geochemicznej charakterystyki osadów kompleksu torfowisk w pobliżu wsi Gaik oraz Winiary. Rozwój niewielkich powierzchniowo zbiorników rozpoczyna faza jeziorna (gytia ilasto-wapienna z kilkuprocentowym udziałem $\mathrm{CaCO}_{3}$ ), a następnie przyjmuje fazy torfowiska niskiego i przejściowego - torfy o różnym stopniu rozkładu i średniej popielności ok. 20\% z liczną malakofauną oraz drewnem.

Również w Owczarach koło Buska-Zdroju obecność w spagu profilu torfowiska gytii ilastej, ilasto-wapiennej i wapiennej z dużym udziałem $\mathrm{CaCO}_{3}$ (ponad 60\%), stanowi zapis sedymentacji organicznej i mineralnej w zbiorniku jeziornym. Objęte ochroną torfowisko, którego misa powstała w warunkach krasu gipsowego, jest obecnie zasilane wodami podziemnymi czterojonowego typu $\mathrm{Cl}-\mathrm{SO}_{4}-\mathrm{HCO}_{3}-\mathrm{Na}, \mathrm{S}$ i stanowi jedyny słonoroślowy rezerwat na terenie Niecki Nidziańskiej (Łajczak, 2000). Materiał pyłkowy w pobranych ostatnio osadach wykazuje niską frekwencję i zły stan zachowania, co uniemożliwia rekonstrukcję historii rozwoju roślinności na tym terenie (Brzozowicz, inf. ustna). Z kolei ze szczegółowych badań Szczepanka (1971) nad osadami biogenicznymi wypełniającymi 11 lejów krasowych w północno-wschodniej części Niecki Nidziańskiej wynika, że pierwsza faza ich rozwoju przypada na późny glacjał (las brzozowo-modrzewiowo-sosnowy oraz zbiorowiska roślin otwartych), druga zaś rozpoczęła się u schyłku okresu atlantyckiego (lasy łęgowe i olszowe w podmokłych obniżeniach oraz lasy sosnowo-dębowe na siedliskach suchych).

Torfowisko Żydowiec, o powierzchni ok. 100 ha, wypełnia rozległe obniżenie krasowo-denudacyjne o długości nieco ponad $1 \mathrm{~km}$ oraz szerokości ok. 0,8-1,2 km (Urban i in., 2012). Od północy, wschodu i południa zagłębienie to otaczają wzgórza, wyniesione względem powierzchni torfowiska o 15-20 m, jedynie na zachodzie obniżenie przechodzi w rozległą dolinę Nidy. Lokalnie miąższość gytii ilastej i ilasto-wapiennej przekracza $1 \mathrm{~m}$, a wynik datowania radiowęglowego (3740 \pm 70 lat BP) warstwy silnie zmurszałego torfu, przykrywającego osady jeziorne, stanowi zapis rozwoju torfowiska niskiego dopiero w późnym holocenie (Alexandrowicz, Żurek, 2013). Z pracy Woźniaka i Żurka (2005) wynika, że spadek udziału $\mathrm{CaCO}_{3}$ w osadach jeziornych i torfowych bliżej powierzchni terenu (z 88\% do 13\%), świadczy o sedymentacji w warunkach stopniowego zmniejszenia zasilania gruntowego.

Na znacznej powierzchni Niecki Nidziańskiej (ok. 75\%), skały podłoża przykrywa zróżnicowana pod względem miąższości seria utworów czwartorzędowych, reprezentowanych przez piaski, pyły oraz gliny, związane głównie $\mathrm{z}$ morfogenezą polodowcową w warunkach klimatu peryglacjalnego i umiarkowanego, w mniejszym stopniu z mor-

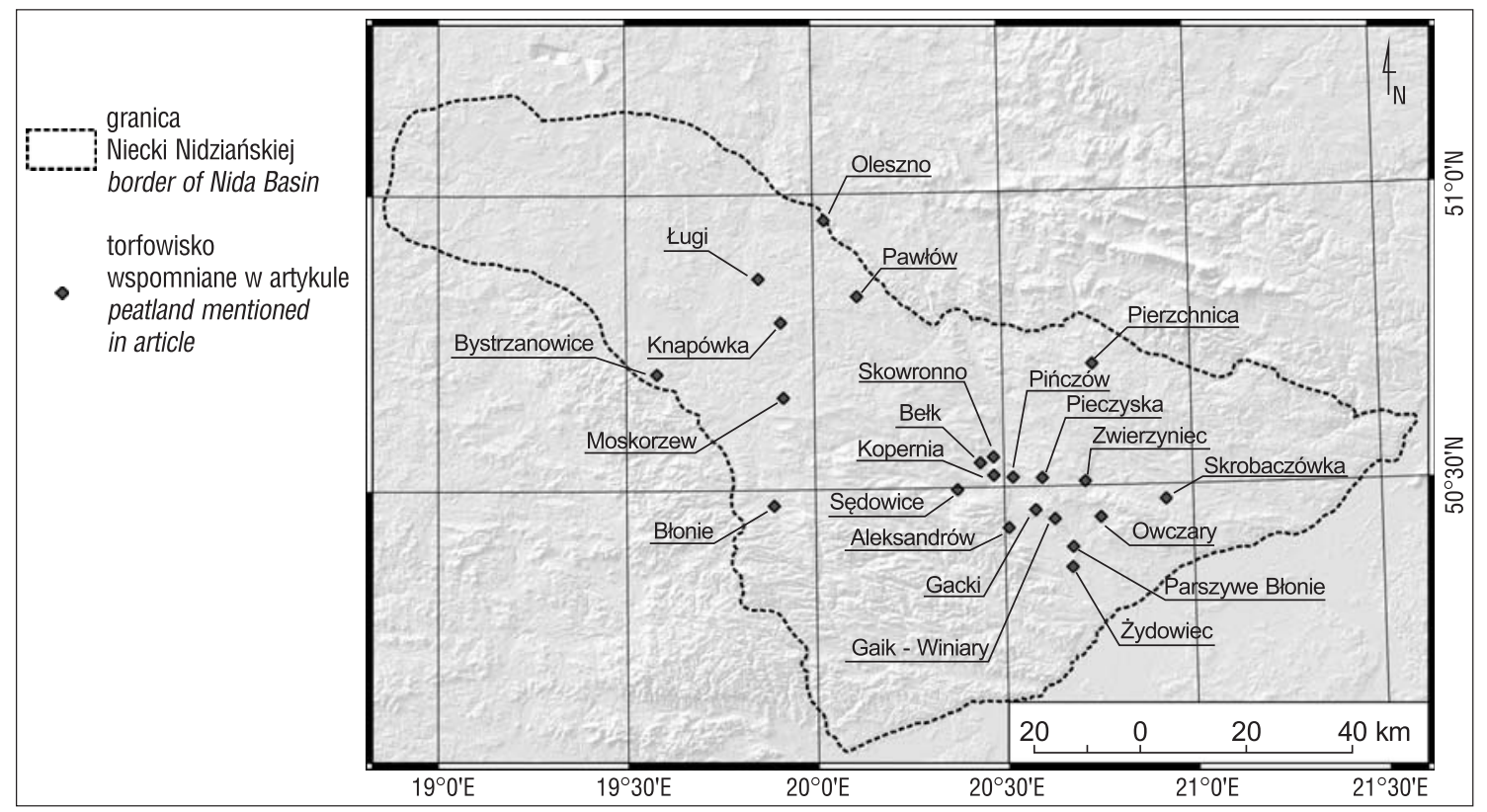

Ryc. 4. Lokalizacja torfowisk opisywanych w artykule

Fig. 4. Location of the peatlands described in article 
fogenezą glacjalną (Cabaj, Nowak, 1986). Złożona budowa geologiczna, w powiązaniu $\mathrm{z}$ parametrami charakteryzującymi rzeźbę terenu (np. spadki terenu czy deniwelacje), zadecydowały o rozwoju licznych siedlisk podmokłych. Na przykład ze względu na niewielki spadek doliny Nidy (ok. 0,5\%o) forma ta jest wypełniona głównie holoceńskimi madami, piaskami, namułami oraz torfami (Hakenberg, Lindner, 1973; Rodzik i in., 2008). Z badań Żurka (1993) wynika, że taka sytuacja jest typowa dla dolin kształtowanych przez wody rzeczne, które sezonowo pokrywają cały jej obszar, a w pozostałej części roku znacząco opadają, nawet poniżej powierzchni równi zalewowej. Mimo dużej amplitudy wahań poziomu wody, to właśnie w dolinach rzecznych stwierdzono występowanie największych powierzchniowo torfowisk Niecki Nidziańskiej, przy czym niektóre z nich przekraczają nawet 200 ha (Żurek, 1981; Lipka, 2000). W takich warunkach przyrost torfu jest jednak niewielki (ok. $0,4 \mathrm{~mm} / \mathrm{rok}$ ), a średnia miąższość osadów torfowisk dolinnych waha się głównie w granicach 0,7-1,5 m i rzadko przekracza $2 \mathrm{~m}$ (Piwocki, 1971; Sołtysik, 1996; Rodzik i in., 2008). Największe powierzchniowo torfowiska dolinne na terenie Niecki Nidziańskiej (np. Błonie, Kopernia, Skowronno), składają się głównie z torfów olesowych i mechowiskowych, rzadziej z turzycowiskowych i szuwarowych (Piwocki, 1971; Żurek, 1981; Lipka, Zając, 2018).

Z badań Jaśkowskiego (2001) oraz Sołtysika (2002) wynika, że misy torfowiskowe występujące w subregionach Niecki Włoszczowskiej, Płaskowyżu Jędrzejowskiego oraz Płaskowyżu Szydłowskiego genetycznie są związane z działalnością eoliczną. W istocie wiele $\mathrm{z}$ nich jest poligenetycznych. Zostały ukształtowane wskutek procesów fluwialnych lub denudacyjnych, ale do ich zamknięcia doszło dopiero w wyniku eolicznej akumulacji piasku w postaci pokryw i wydm. Przykłady takich torfowisk występują zarówno w małych dolinach rzecznych (np. Jeżówka Kuźniecka), jak i większych, np. w górnej Pilicy (na odcinku Żarnowiec-Szczekociny). Część z nich została objęta ochroną rezerwatowa, np. torfowiska Ługi k. Jeżowic czy Pieczyska (Żurek, 2006). Przykładem zatorfionego zagłębienia przywydmowego jest stosunkowo rozległe (200 ha) torfowisko Knapówka, oddalone o $8 \mathrm{~km}$ na południe od Włoszczowy. $\mathrm{Z}$ wyników analiz palinologicznej i diatomologicznej wynika, że funkcjonujący w okresie późnego glacjału zbiornik jeziorny uległ zatorfieniu w starszej części holocenu (Kaczmarska, 1973). Zróżnicowana litologia wypełnienia opisywanego zbiornika, w tym wkładki namułów oraz piasków, świadczą o wzmożonej aktywności powodziowej lub też eolicznej. Taka sytuacja, dowodząca przerywania sedymentacji biogenicznej, zgodnej z szeregiem sukcesyjnym (stopniowego wypełniania misy zbiornika jeziornego oraz lądowacenia prowadzącego do całkowitego zniknięcia jeziora i rozwoju torfowiska), często jest spotykana w torfowiskach limnogenicznych centralnej Polski (Forysiak, 2013; Żurek, Okupny, 2015). Na uwagę zasługują także torfowiska: Oleszno, o południkowym przebiegu i maksymalnej miąższości torfu 5,3 m, ograniczone od zachodu stokiem kompleksu eolicznego z wydmami (Piwocki, 1971; Sołtysik, 2000) oraz Pawłów, z miąższością torfu rzędu 0,5-3,5 m, przylegające od wschodu do wydmy Michałów (Cabaj, Nowak, 1986). Zagłębienia w pobliżu wydm stosunkowo często powstawały w wyniku działalności deflacyjnej (aż 8\% torfowisk udokumentowanych na SMGP).
Cechami torfowisk wypełniających tego typu formy są: niewielka powierzchnia (zazwyczaj 1-2 ha), średnia miąższość osadów biogenicznych nie przekraczająca $0,8 \mathrm{~m}$, a maksymalna, w przegłębianiach ich środkowych części, wynosząca zaledwie 1,5 m (Żurek, 1981; Sołtysik, 2000, 2002; Jaśkowski, 2001).

Na terenie Niecki Nidziańskiej licznie występują także torfowiska powstałe $\mathrm{w}$ zagłębieniach krasu reprodukowanego. Genezę tych zbiorników, przyjmujących najczęściej kształt lejów, niecek i rynien, należy wiązać z krążeniem wód podziemnych pod pokrywą skał luźnych (Walczowski, 1964; Liszkowski, 1979; Nowak, 1993). Nad miejscami przenikania materiału pokrywowego w szczeliny krasowe tworzą się na powierzchni terenu bezodpływowe formy wklęsłe, które w zachodniej i północnej części Wyżyny Małopolskiej są wypełnione osadami mineralno-organicznymi, gytiami węglanowymi oraz torfami (Żurek, 1981; Kobojek, Nalej, 2008; Brzozowicz, Forysiak, 2016; Okupny i in., 2016). Najwięcej zatorfionych zagłębień o takiej genezie występuje na terenie Niecki Nidziańskiej u podnóża progu w rejonie Lelowa (Żurek, 1981; Cabaj, Nowak, 1986) oraz na Płaskowyżu Szydłowskim i w Niecce Połanieckiej w rejonie Staszowa (Szczepanek, 1971; Zieliński, 2013). Maksymalną miąższość torfu, dochodzącą nawet do 4,5 m, udokumentowano w okolicy Bystrzanowic i Moskarzewa (ryc. 4).

\section{CHARAKTERYSTYKA OSADÓW WYBRANYCH TORFOWISK ŹRÓDLISKOWYCH}

Torfowiska źródliskowe stanowią rzadką grupę niskich torfowisk soligenicznych, których osobliwości przyrodnicze dotyczą morfologii, hydrologii, geobotaniki oraz litologii osadów (Tobolski, 2003; Dobrowolski, 2011). Terminologia stosowana do określania źródliskowych osadów węglanowych jest problemem dyskusyjnym (Szulc, 1983; Dobrowolski, 2011; Capezzuoli i in., 2014). Osady węglanowe wytrącające się w strefie wypływu wód podziemnych często występują naprzemiennie z utworami organicznymi (torfami), co umożliwia prowadzenie badań z zakresu rekonstrukcji paleogeograficznych i chronostratygraficznych (Dobrowolski i in., 1999, 2016; Apolinarska, Gałka, 2017; Gruszczyński i in., 2017; Pietruczuk i in., 2018).

W wyniku kartowania torfowisk źródliskowych, na terenie Niecki Nidziańskiej określono warunki hydrogeologiczne oraz geomorfologiczne trzech stanowisk: Bełk, Sędowice i Zwierzyniec. Średnia miąższość osadów organiczno-węglanowych torfowiska Bełk, usytuowanego na zachód od Pińczowa (ryc. 5A), wynosi ok. 1,2 m, przy czym maksymalna przekracza nieco $3 \mathrm{~m}$. Torfowisko to leży w dolinie Kruczki (Mierzawki), będącej prawobrzeżnym dopływem Nidy, i ma powierzchnię 39 ha. W profilu osadów pobranych w środkowej części tego torfowiska przeważają torfy mszysto-turzycowe o 20-60-procentowym rozkładzie oraz średnim udziale materii mineralnej (w tym węglanowej) przekraczającym 20\%. Ponadto udokumentowane torfy są smugowane i warstwowane cienkimi wkładkami martwicy mułkowej (z udziałem $\mathrm{CaCO}_{3}$ rzędu 50-80\%), które makroskopowo przypominają gytię wapienną i kredę jeziorną. Podobnie jak w górnych odcinkach większości pozostałych dolin rzecznych Płaskowyżu Jędrzejowskiego dopływ wód podziemnych do torfowiska następuje z po- 
łudniowego zachodu, poprzez miąższy poziom piasków fluwioglacjalnych ze żwirami (Łyczewska, 1968).

Torfowisko w Sędowicach (ryc. 5B) tworzą torfy o średnim i silnym stopniu rozkładu, z licznymi przewarstwieniami martwicy wapiennej, które wypełniają dno doliny Mierzawy. Zdaniem Łyczewskiej (1968) mezozoiczne podłoże, wyniesione na zachód od torfowiska, jest marglistym ostańcem denudacyjnym. Średnia miąższość osadów biogenicznych tego torfowiska nie przekracza $1 \mathrm{~m}$, jednak ze względu na prowadzoną eksploatację torfu oraz funkcjonowanie stawów hodowlanych na wschód od ujścia Mozgawy, jest to wartość szacunkowa. Zawartość $\mathrm{CaCO}_{3}$ waha się od 52\% w martwicy mułkowej do $87 \%$ w martwicy drobnoziarnistej.

Największą miąższość osadów torfowo-węglanowych (ponad 4,5 m) udokumentowano na północ od Buska-Zdroju w torfowisku źródliskowym w Zwierzyńcu-Mikułowicach na terenie Szanieckiego Parku Krajobrazowego (ryc. 5C). Dominują w nim torfy mszyste $-\mathrm{Tb}^{2} 4, \mathrm{Lc}++$, sicc.2, elas.2, nig.3, lim.3; torfy turzycowo-mszyste $\mathrm{z}$ fragmentami drewna - $\mathrm{Sh} 2, \mathrm{~Tb}^{3} 1, \mathrm{Th}^{3} 1, \mathrm{Tl}+, \mathrm{Ld}+$, sicc. 2 , elas.2, nig.4, lim.0; martwice gruboziarniste $\mathrm{z}$ malakofauną - $\mathrm{Cm}$ (min.)4, sicc.2, elas.1, nig.1, lim.1, [teste (moll.)2] oraz martwice bardzo gruboziarniste $\mathrm{Cm}$ (maj.)3, $\mathrm{Tb}^{2} 1$, sicc.2, elas.1, nig.1., lim.0. Opisywany ekosystem tworzy kompleks torfowisk soligenicznych, zlokalizowanych w licznych zgłębieniach bezodpływowych w strefie wododziałowej w wapieniach Garbu Piń- czowskiego oraz na jego południowych zboczach, w miejscach wypływu wód podziemnych. Lokalizacja torfowiska w Zwierzyńcu (profil Z-I) świadczy o tym, że występujące nieopodal źródła są descensyjne. Wypływy wód z krawędzi niszy cechują się odczynem obojętnym i lekko zasadowym (pH w granicach 7,2-7,8) i twardością ogólną na poziomie 5,2-7,4 mval/1. Z dokumentacji hydrogeologicznej pobliskiego ujęcia wody (Siemieniec, 2002) wynika, że pod względem składu chemicznego wody podziemne należą do wodorowęglanowo-wapniowych, typowych dla obszarów wyżynnych (Dynowska, 1979; Michalczyk, 1997), w tym także Niecki Nidziańskiej (Chełmicki, 1986; Wicik, 2000a).

Zróżnicowane genetycznie osady torfowiska w Zwierzyńcu (ryc. 5D) stanowią zapis zmieniającej się w czasie wydajności zasilania wodami podziemnymi. W profilu Z-I wyróżniono 3 zasadnicze jednostki litologiczne: osady ilaste $\mathrm{z}$ niewielką domieszką materii organicznej (2-5\%) oraz $\mathrm{CaCO}_{3}(5-8 \%)$; osady martwicy wapiennej o różnym stopniu zwietrzenia i średnim udziale $\mathrm{CaCO}_{3}$ przekraczającym $72 \%$ oraz silnie rozłożone i zamulone torfy ze średnim udziałem materii organicznej nie przekraczającym $45 \%$. W brzeżnej części torfowiska zmniejsza się wyraźnie udział martwicy wapiennej, wzrasta zaś udział silnie rozłożonego torfu ze stosunkowo dużą ilością $\mathrm{CaCO}_{3}(20-40 \%)$ oraz osadów ilasto-mułowych ze średnim udziałem materii organicznej ok. $15 \%$ oraz $\mathrm{CaCO}_{3}$ maksymalnie do $25 \%$. (ryc. 6).

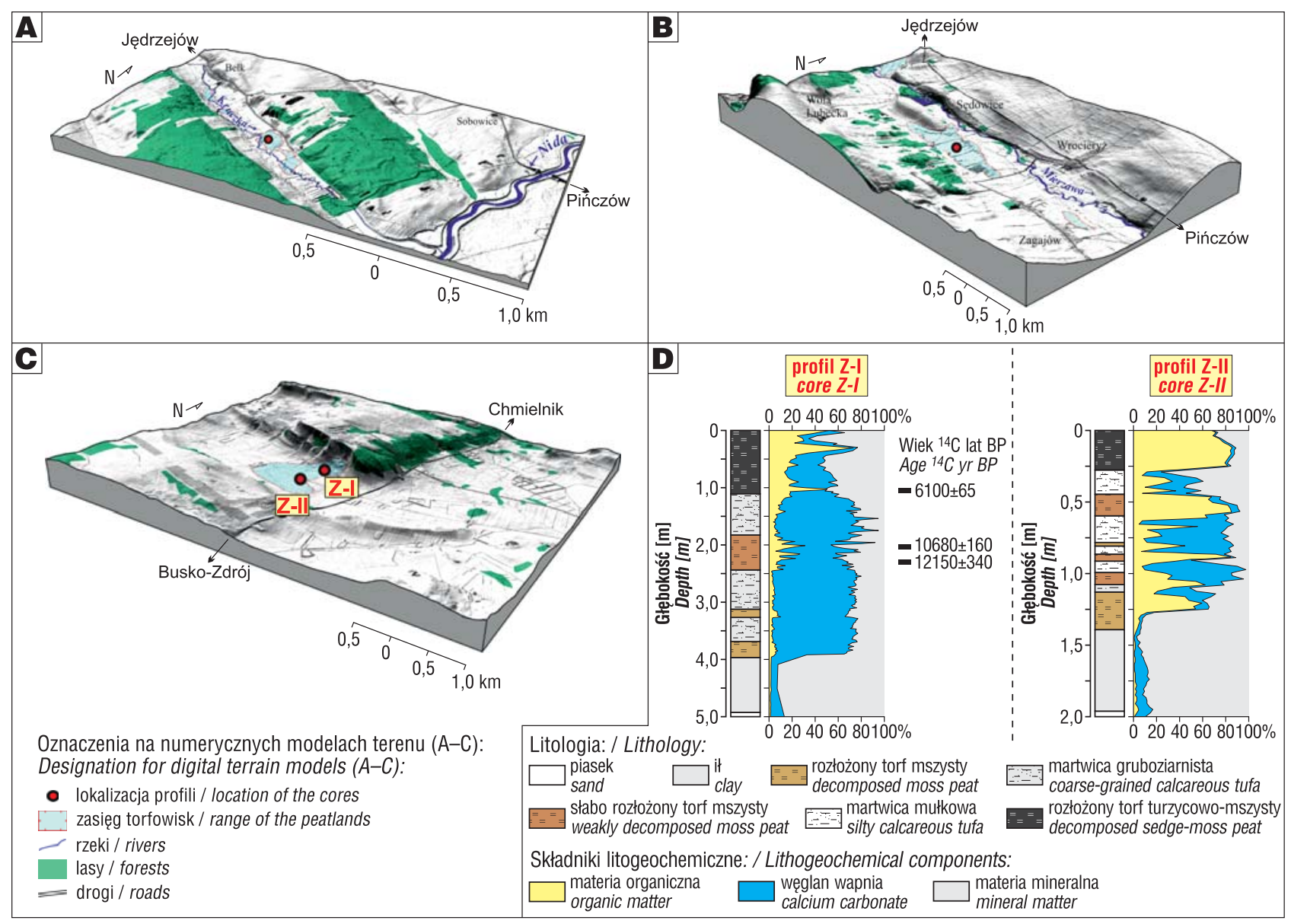

Ryc. 5. Lokalizacja torfowisk źródliskowych: A - w dolinie Kruczki; B - w dolinie Mierzawy; C - na południowym zboczu Garbu Pińczowskiego; oraz D - główne składniki litogeochemiczne profili ze stanowiska Zwierzyniec-Mikułowice

Fig. 5. Location of the spring-fed fens: A-in the Kruczka River valley; B - in the Mierzawa River valley; $\mathbf{C}$ - on the southerh slope of the Pińczów Hump); and D - main lithogeochemical components of the profiles from the Zwierzyniec-Mikułowice site 


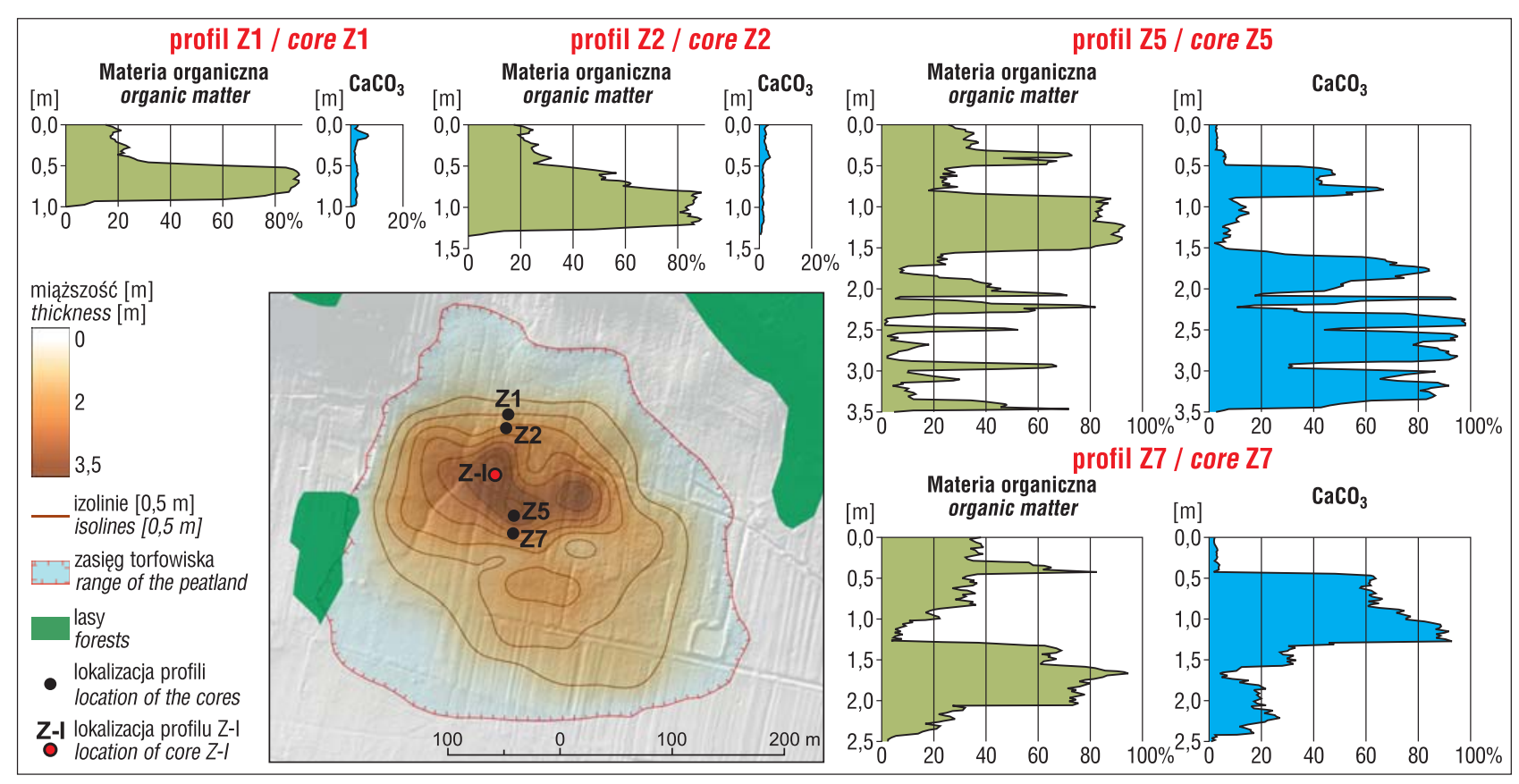

Ryc. 6. Stanowisko Zwierzyniec (torfowisko źródliskowe) - szkic miąższości osadów oraz ich podstawowe cechy geochemiczne Fig. 6. Zwierzyniec site (spring-fed fen) - sketch of the thickness of deposits and their basic geochemical features

Wyniki datowania radiowęglowego osadów torfowych w środkowej części profilu Z-I: $12150 \pm 340$ lat BP (głębokość $2,25-2,3 \mathrm{~m}$ ) i $10680 \pm 160$ lat BP (głębokość 2,05-2,10 m), sugerują późnoglacjalną aktywność źródeł w tej części Niecki Nidziańskiej. Funkcjonowaniu obiektów krenologicznych mogły sprzyjać: morfologia terenu (nachylenie przekraczające $30 \%$, południowa ekspozycja zbocza) oraz duża porowatość całkowita mioceńskich wapieni detrytycznych podścielających zlewnię, wynosząca od 18,4 do 37,4\% (Rutkowski, 1969; Kozłowski, Leszczyszyn, 1986). Uwage zwraca także duża porowatość efektywna tych wapieni, decydująca o ich wodoprzepuszczalności. Jest ona skutkiem tego, że w podłożu tej zlewni występują wapienie z przewarstwieniami żwirów (ze średnim udziałem $\mathrm{CaCO}_{3}$ ok. 53\%), lokalnie przykryte cienką warstwą utworów piaszczysto-pylastych (Marszałek, 1970; Siemieniec, 2002). Ponadto w kształtowaniu stosunków hydrogeologicznych opisywanego obszaru ważną rolę odgrywają uskoki. Dyslokacje starszej generacji przecinają utwory kredy i bade$\mathrm{nu}$, natomiast uskoki młodszej generacji obejmują też osady sarmatu detrytycznego (Rutkowski, 1981). Zanik depozycji węglanowej, wyznaczony przez wynik datowania radioweglowego $6100 \pm 60$ lat $\mathrm{BP}$, przypada na druga część fazy AT3 (Starkel i in., 2013) w optimum klimatycznym holocenu. Potwierdza to wyniki dotychczasowych badań dotyczących wpływu pogorszenia się mezoholoceńskich warunków hydroklimatycznych na zmniejszenie wytrącania martwic wapiennych w południowej i wschodniej Polsce (Dobrowolski i in., 1999; Pazdur i in., 1988).

W zupełnie innych warunkach zachodziła sedymentacja holoceńskiej martwicy wapiennej w zachodniej części Garbu Pińczowskiego. Jej rozwój, zdaniem Alexandrowicza i Gołas-Siarzewskiej (2013), nastąpił w niewielkim zbiorniku wodnym, który powstał w średniowieczu na zapleczu grobli trawertynowej. Z kolei współczesne warunki wytracania martwicy wapiennej w korycie niewielkiego cieku Skrobaczówka, należącego do zlewni Czarnej Staszowskiej, opisał Bonk (2016).

\section{PODSUMOWANIE}

Przedstawiony materiał badawczy dowodzi wyraźnego związku przestrzennego rozmieszczenia torfowisk z budową geologiczną oraz rzeźbą terenu. Subregionami o zdecydowanej przewadze torfowisk są Niecka Włoszczowska, Dolina Nidy oraz Płaskowyż Jędrzejowski i Płaskowyż Lelowski. Z kolei Wyżyna Miechowska i Działy Proszowickie są obszarami o niewielkiej liczbie torfowisk, rozwijających się głównie w zagłębieniach o powierzchni do 5 ha.

Współczesne torfowiska Niecki Nidziańskiej powstały w obrębie form poligenicznych, których rozwój był związany ze strukturą tektoniczną (np. Garb Pińczowski), krasem w warunkach skał węglanowych i gipsowych (np. Płaskowyż Jędrzejowski, Niecka Połaniecka, Niecka Solecka), funkcjonowaniem krasu reprodukowanego (np. Płaskowyż Lelowski, Niecka Połaniecka), rzeźbotwórczą działalnością fluwialną i eoliczną (Dolina Nidy, Niecka Włoszczowska) oraz rozcięciem poziomów wodonośnych i powstaniem lokalnie nisz źródliskowych (np. Płaskowyż Jędrzejowski, Garb Pińczowski). W strukturze osadów torfowiskowych badanego obszaru dominują torfy niskie, lokalnie silnie zamulone.

W warunkach stałej alimentacji wodami podziemnymi bogatymi w $\mathrm{CaCO}_{3}$ rozwinęły się torfowiska źródliskowe z serią rytmicznie warstwowanych torfów i martwic wapiennych o miąższości dochodzącej maksymalnie do $5 \mathrm{~m}$. Określony radiowęglowo początek depozycji osadów węglanowych w Zwierzyńcu koło Buska-Zdroju przypada na późny glacjał, a paludyzacja (zatorfienie) ekosystemu i sedentacja silnie rozłożonego torfu turzycowo-mszystego była związana prawdopodobnie $\mathrm{z}$ pogorszeniem się warunków hydrotermicznych w mezoholocenie. Czynnikiem decydującym o uruchomieniu zasilania źródliskowego były lokalne uwarunkowania hydrogeologiczne i geomorfologiczne na południowym zboczu Garbu Pińczowskiego.

Ze względu na naturalne zmiany hydroklimatyczne oraz działalność człowieka, przejawiającą się w eksploata- 
cji torfu, konieczne jest kontynuowanie badań nad chronostratygrafią i paleogeografią Niecki Nidziańskiej na podstawie interdyscyplinarnych analiz osadów torfowych i martwic wapiennych. Mimo największej wartości wskaźnika zatorfienia w pasie Wyżyn Polskich, wciąż brakuje szczegółowych rekonstrukcji paleośrodowiskowych Niecki Nidziańskiej, co uniemożliwia porównanie zapisu zmian środowiska ostatnich kilkunastu tysięcy lat $\mathrm{z}$ innymi obszarami. Zagadnienie to jest szczególnie istotne również w kontekście stosunkowo dużej liczby form ochrony przyrody i zróżnicowania środowisk sedymentacyjnych Niecki Nidziańskiej.

Badania terenowe zostały zrealizowane w ramach projektu naukowego sfinansowanego przez Rektora Uniwersytetu Pedagogicznego pt. Osady torfowisk źródliskowych i ich środowiska sedymentacyjne $w$ środkowej i poludniowej Polsce (nr projektu BN.3115-153/217/R). Badania z zakresu chronostratygrafii martwic wapiennych zostały sfinansowane przez Narodowe Centrum Nauki w ramach projektu MINIATURA-1 pt. Geneza i sktad chemiczny osadów biogeniczno-węglanowych budujacych torfowisko źródliskowe w okolicy Buska-Zdroju (Niecka Nidziańska) o numerze: 2017/01/X/ST10/00525. Słowa podziękowania autorzy kierują do Regionalnej Dyrekcji Ochrony Środowiska w Kielcach i Zespołu Świętokrzyskich i Nadnidziańskich Parków Krajobrazowych za wyrażenie zgody na prowadzenie badań na terenach objętych ochroną oraz do Miejskiego Przedsiębiorstwa Gospodarki Komunalnej w Busku-Zdroju za udostępnienie archiwalnych materiałów hydrogeologicznych. Autorzy składaja podziękowania redaktorowi numeru tematycznego dr. hab. inż J. Urbanowi oraz recenzentom, prof. dr. hab. R. Dobrowolskiemu i śp. prof. dr. hab. J. Szulcowi, za wnikliwą recenzję artykułu oraz wiele konstruktywnych uwag.

\section{LITERATURA}

ALEXANDROWICZ S.W., BAŁAGA K., DOBROWOLSKI R. 1994 Etapy rozwoju torfowiska kopułowego Krzywice w okolicach Chełma Lubelskiego. Kwart. AGH - Geologia, 20 (3): 259-273.

ALEXANDROWICZ W.P., GOŁAS-SIARZEWSKA M. 2013 - Zmiany środowiska Niecki Nidziańskiej (południowa Polska) w świetle analizy malakologicznej martwic wapiennych w Pińczowie. Biul. Państw. Inst. Geol., 454: 1-14.

ALEXANDROWICZ S.W., ŻUREK S. 1996 - Origin and malacofauna of spring mire in the Tyśmienica River valley (Western Polesie). Kwart. AGH - Geologia, 20 (3): 259-273.

ALEXANDROWICZ W.P., ŻUREK S. 2013 - Holocene malacofauna from a peat bog in Żydowiec, near Wiślica (Nida Basin, Southern Poland). Folia Malacol., 21: 161-170

APOLINARSKA K., GAŁKA M. 2017 - Detrital input to spring-fed fen deposits - a problem or an opportunity in palaeoenviornmental studies? A Holocene palaeoclimatic reconstruction from central Europe. J. Quatern. Sci., 32 (1): 91-103.

BARBER K.E. 1993 - Peatlands as scientific archives of past biodiversity. Biodivers. Conserv., 2: 474-489.

BONK M. 2016 - Stwierdzenie martwicy wapiennej w gminie Stopnica (woj. świętokrzyskie). Wszechświat, 117: 316-317.

BRZOZOWICZ D., FORYSIAK J. 2016 - Warunki funkcjonowania i rozwój torfowiska w zagłębieniu krasowym w okolicach Paradyża. Acta Geogr. Lodz., 105: 69-79.

CABAJ W., NOWAK W.A. 1986 - Rzeźba Niecki Nidziańskiej. Stud. Ośr. Dokument. Fizjogr., 14: 119-209.

CAPEZZUOLI E., GANDIDN A., PEDLEY M. 2014 - Decoding tufa and travertine (fresh water carbonates) in the sedimentary record: The state of the art. Sedimentology, 61: 1-21.

CHEŁMICKI W. 1986 - Źródła Niecki Nidziańskiej. Stud. Ośr. Dokument. Fizjogr., 14: 249-271

DOBROWOLSKI R. 1994 - Tektoniczne uwarunkowania rozwoju źródliskowego torfowiska kopułowego Krzywice koło Chełma. Prz. Geol., 7: 532-535.

DOBROWOLSKI R. 2011 - Problemy klasyfikacyjne osadów torfowisk źródliskowych. Stud. Lim. Tel., 5, 1: 3-12.

DOBROWOLSKI R., ALEXANDROWICZ S.W., BAŁAGA K., DUARKIEWICZ T., PAZDUR A. 1999 - Badania martwic wapiennych w obrębie źródliskowych torfowisk kopułowych we wschodniej Polsce. [W:] A. Pazdur, A. Bluszcz, W. Stankowski, L. Starkel, Geochronologia górnego czwartorzedu Polski w świetle datowań radioweglowych i luminescencyjnych. WIND - J. Wojewoda, Wrocław: 179-197.

DOBROWOLSKI R., BAŁAGA K., BUCZEK A., ALEXANDROWICZ W.P., MAZUREK M., HAŁAS S., PIOTROWSKA N. 2016 - Multi-proxy evidence of Holocene climate variabilty in Volhynia Upland (SE Poland) recorded in spring-fed fen deposits from the Komarów site. The Holocene, 26 (9): 1406-1425.

DOBROWOLSKI R., DURAKIEWICZ T., PAZDUR A. 2002 - Calcareous tufas in the soligenous mires of eastern Poland as an indicator of the Holocene climatic changes. Acta Geol. Pol., 52 (1): 63-73.

DOBROWOLSKI R., MAZUREK M., OSADOWSKI Z., ALEXANDROWICZ W.P., PIDEK I.A., PAZDUR A., PIOTROWSKA N., DRZY MULSKA D., URBAN D. 2019 - Holocene environmental changes in northern Poland recorded in alkaline spring-fied fen deposits - A multi-proxy approach. Quat. Sci. Rev., 219: 236-262.

DYNOWSKA I. 1979 - Charakterystyka źródeł Wyżyny Krakowsko-Wieluńskiej. Stud. Ośr. Dokument. Fizjogr., 7: 391-421.

FLIS J. 1954 - Kras gipsowy Niecki Nidziańskiej. Pr. Geogr. IG PAN, 1: $5-73$.

FORYSIAK J. 2012 - Zapis zmian środowiska przyrodniczego późnego vistulianu i holocenu w osadach torfowisk regionu łódzkiego. Acta Geogr. Lodz., 99: 1-164.

FORYSIAK J. 2013 - Jeziorna przeszłość torfowisk regionu łódzkiego. Acta Univ. Lodz., Folia Geogr. Phys., 12: 3-15.

GAŁKA M., PASIECZNA A., TOMASSI-MORAWIEC H., OSSENDOWSKA E., NOWACKI K., SALAMON E., NIEĆ M. 2006-Objaśnienia do Mapy Geośrodowiskowej Polski, ark. Busko-Zdrój (917) 1:50 000. Państw. Inst. Geol. Warszawa.

GŁAZEK T. 1989 - Nowe dla Polski południowej stanowisko Schoenus nigricans L. Fragm. Flor. Geobot., 34 (3-4): 249-253.

GŁAZEK T. 1992 - Lipario-Scheonetum ferruginei - a new platn association. Fragm. Flor. Geobot., 37 (2): 549-562.

GORHAM E. 1991 - Northern peatlands: role in the carbon cycle and probable responses to climatic warming. Ecol. Appl., 1: 182-195.

GRUSZCZYŃSKI T., MAŁECKI J., ZIUŁKIEWICZ M. 2017 - Reconstruction of palaeohydrological conditions in the Late Holocene based in the study of calcareous tufa in the spring mire of the Wolbórka river drainage basin (central Poland). J. Elementol., 22 (3): 1049-1065.

HAKENBERG M., LINDNER L. 1973 - Holoceński rozwój doliny środkowej Nidy. Acta Geol. Pol., 23: 435-444.

HERMAN G., GA_GOL J. 2000 - Wody mineralne w rejonie Buska-Zdroju i Solca-Zdroju. Prz. Geol., 48: 616-618.

JANICKI G., RODZIK J., TYC A. 2008 - Zastosowanie kryterium litologicznego w typologii krajobrazu naturalnego Wyżyn Polskich. Probl. Ekol. Krajobr., 20: 99-107.

JASNOWSKI M. 1975 - Torfowiska i tereny bagienne w Polsce. [W:] Kac N.J., Bagna kuli ziemskiej. PWN, Warszawa: 356-390.

JAŚKOWSKI B. 2001 - Zwiazek procesów wydmotwórczych z wystepowaniem mokradeł i torfowisk w Regionie Świętokrzyskim. Woda-Środowisko-Obszary Wiejskie, 1 (3): 179-195.

JÓŹWIAK K., RÓŻKOWSKI J. 2015 - Charakterystyka występowania mikroskładników w lokalnych systemach przepływu wód podziemnych w środowisku skał weglanowych i siarczanowych Niecki Nidziańskiej. Prz. Geol., 63: 796-800.

KACZMARSKA I. 1973 - Late-Glacial datom flora at Knapówka near Włoszczowa (South Poland). Acta Palaeobot., 14 (3): 173-199.

KARSKI A. 1971 - Kilka uwag o zaopatrzeniu uzdrowisk w borowinę. Biul. Inf. Torf, 3: 17-20.

KOBOJEK S., NALEJ M. 2008 - Formy krasu reprodukowanego w południowej części Wyżyny Wieluńskiej. Landform Analysis, 9: 247-250. KOZŁOWSKI S. LESZCZYSZYN H. 1986 - Surowce mineralne Niecki Nidziańskiej. Stud. Ośr. Dokument. Fizjogr., 14: 63-85.

LAMENTOWICZ M. 2007 - Paleoekologia torfowisk - źródło informacji o historii klimatu i wpływie człowieka na środowisko. Prz. Geol., 55 $(12 / 2): 1130-1135$

LINDNER L. 1984 - Region świętokrzyski. [W:] E. Mojski (red.), Budowa geologiczna Polski, t. 1. Stratygrafia, cz. 3b, Kenozoik. Czwartorzęd. Wyd. Geol., Warszawa: 282-287.

LIPKA K. 2000 - Torfowiska w dorzeczu Wisły jako element środowiska przyrodniczego. Zesz. Nauk. AR w Krakowie, Ser. Rozprawy, 255: 1-148. LIPKA K., ZAJĄC E. 2018 - Hydrological conditions of peatland formation based on a dynamic curve of a biogenic sediments sequence - a new proposal. J. Water and Land Develop., 37: 75-85.

LISZKOWSKI J. 1979 - Typy morfogenetyczne oraz mechanizmy rozwoju powierzchniowego form krasu zakrytego w Polsce. Biul. Geol. Wydz. Geol. Uniw. Warsz., 23: 155-169.

ŁACHACZ A. 2004 - Mokradła w krajobrazie - wybrane pojęcia. Woda-Środowisko-Obszary Wiejskie, 4 (2): 295-301. 
ŁAJCZAK A. 2000 - Zagrożenia i ochrona źródeł mineralnych na Ponidziu na przykładzie rezerwatu przyrody Owczary. Chr. Przyr. Ojcz., 5: 43-76.

ŁAJCZAK A. 2013 - Zmniejszenie zasięgu złóż torfu i ich retencji wodnej w Kotlinie Orawsko-Nowotarskiej i w Bieszczadach w wyniku działalności człowieka. Prz. Geol., 61: 532-540.

ŁAWRYNOWICZ M. 1977 - Torfowiska źródliskowe z turzycą Davalia w okolicach Mstowa koło Częstochowy. Chr. Przyr. Ojcz., 4: 63-66.

ŁYCZEWSKA J. 1968 - Szczegółowa mapa geologiczna Polski w skali 1:50 000, ark. Jędrzejów. Państw. Inst. Geol., Warszawa.

ŁYCZEWSKA J. 1975 - Zarys budowy geologicznej Pasma Wójczo-Pińczowskiego. Biul. Inst. Geol., 283: 151-189.

MARCISZ K., LAMENTOWICZ Ł., SŁOWIŃSKA S., SŁOWIŃSKI M. MUSZAK W., LAMENTOWICZ M. 2014 - Seasonal changes in Sphagnum peatland testate amoeba communities along a hydrological gradient. Europ. J. Protistol., 50: 445-455.

MARSZAŁEK Z. 1970 - Projekt badań geologicznych studzien na terenie Buska-Zdroju. Arch. Przedsiębiorstwa Hydrogeologicznego, Dział Dokumentacji Geologicznej, nr ewidencyjny 70-4074, Łódź: 1-35.

MAZUREK M., DOBROWOLSKI R., OSADOWSKI Z. 2014 - Geochemistry of deposits from spring-fed fens in West Pomerania (Poland) and its significance for palaeoenvironmental reconstruction. Quatern. Geomorph., 20 (4): 323-342.

MICHALCZYK Z. 1997 - Źródła Wyżyny Lubelskiej i Roztocza. Acta Univ. Lodz., Folia Geogr. Phys., 2: 73-93.

MIGOŃ P., KASPRZAK M. 2014 - Tereny podmokłe na płaskowyżu Gór Stołowych w świetle parametryzacji powierzchni na podstawie topograficznego indeksu wilgotności (TWI). Stud. Lim. Tel., 8: 57-68.

NOWAK W.A. 1993 - Skrasowienie podziemne wapieni i jego odzwierciedlenie w rzeźbie Wyżyny Krakowsko-Wieluńskiej w rejonie Częstochowy. Stud. Ośr. Dokument. Fizjogr., 21: 9-157.

OKUPNY D., GEBUS-CZUPYT B., ALEXANDROWICZ W.P., MICZCZYŃSKI A. 2018 - Badania martwic wapiennych budujących złoża torfowisk źródliskowych w okolicach Buska-Zdrój. [W:] Kostrzewsk A.,. Stach A, Majewski M. (red.), Geneza, litologia i stratygrafia utworów czwartorzędowych. Wyd. Nauk. UAM, Poznań: 141-146. OKUPNY D., NITA M., KLOSS M., ALEXANDROWICZ W.P., FORTUNIAK A., ŻUREK S. 2016 - Próba rekonstrukcji rozwoju zbiornika akumulacji biogenicznej w Bydlinie (Wyżyna Śląsko-Krakowska). Acta Geogr. Lodz., 105: 55-68.

PAZDUR A., DOBROWOLSKI R., DURAKIEWICZ T., PIOTROWSKA N., MOHANTI M., DAS S. $2002-\delta 13 \mathrm{C}$ and $\delta 18 \mathrm{O}$ time record and palaeoclimatic implications of the Holocene calcareous tufa from South-Eastern Poland and Eastern India (Orissa). Geochronometria, 21: 97-108.

PAZDUR A., PAZDUR M.F., STARKEL L., SZULC J. 1988 - Stable isotopes of Holocene calcareous tufa in Southern Poland as paleoclimatic indicators. Quat. Res., 30: 177-189.

PIETRUCZUK J., DOBROWOLSKI R., PIDEK I.A., URBAN D. 2018 - Palaeoecological evolution of spring-fed fen in Pawłów (eastern Poland). Grana, 57 (5): 345-363.

PIWOCKI M. 1971 - Stan rozpoznania złóż torfu województwa kieleckiego. Prz. Geol., 19 (2): 74-76.

PRAŻAK J. 2012 - Wody podziemne, słodkie i lecznicze. [W:] Świercz A. (red.), Monografia Nadnidziańskiego Parku Krajobrazowego. Wyd. UJK w Kielcach, Kielce: 177-185.

PRZEMYSKI A., WOŁEJKO L. 2011 - Calcareous fens of the Nida Basin. Newsletter IMCG, 4: 44-48.

RODZIK J., CIUPA T., JANICKI G., KOCIUBA W., TYC A., ZGŁOBICKI W. 2008 - Współczesne przemiany rzeźby Wyżyn Polskich. [W:] Starkel L., Kostrzewski A., Kotarba A., Krzemień K. (red.), Współczesne przemiany rzeźby Polski. IGiGP UJ, Kraków: 165-228.

RUTKOWSKI J. 1969 - Uwagi o sedymentacji detrytycznych osadów sarmatu na obrzeżeniu Gór Świętokrzyskich. Geol. Quart., 13: 177-184. RUTKOWSKI J. 1981 - O tektonice utworów mioceńskich w zachodniej części zapadliska połanieckiego. Ann. Soc. Geol. Poloniae, 51: 117-131. RUTKOWSKI J. 1986 - Budowa geologiczna Niecki Nidziańskiej. Stud. Ośr. Dokument. Fizjogr., 14: 35-61.

SIEMIENIEC A. 2002 - Sprawozdanie z wykonanych prac i badań w związku z renowacją studni głębinowej dla wsi Zwierzyniec, gmina Busko-Zdrój. Przedsiębiorstwo Budownictwa Ekologicznego, Kielce: 1-6. SOLON J., BORZYKOWSKI J., BIDŁASIK M., RICHLING A., BADORA K., BALON J., BRZEZIŃSKA-WÓJCIK T., CHABUDZIŃSKI Ł., DOBROWOLSKI R., GRZEGORCZYK I., JODŁOWSKI M., KISTOWSKI M., KOT R., KRĄŻ P., LECHNIO J., MACIAS A., MAJCHROWSKA A., MALINOWSKA E., MIGOŃ P., MYGA-PIĄTEK U., NITA J., PAPIŃSKA E., RODZIK J., STRZYŻ M., TERPILOWSKI S., ZIAJA W. 2018 - Physico-geographical mesoregions of Poland: Verification and adjustment of boundaris on the basis of contemporary spatial data. Geograph. Pol., 91 (2): 143-170.
SOLOVEY T., JÓŹWIAK K. 2019 - Skład chemiczny wód podziemnych w strefie kontaktu z siedliskami hydrogenicznymi. Biul. Państw. Inst. Geol., 476: 115-122.

SOŁTYSIK R. 1996 - Torfowiska oraz obniżenia z wypełnieniem biogeniczno-mineralnym okolic Pińczowa w Niecce Nidziańskiej. Pr. Inst. Geogr. WSP w Kielcach, 1: 163-171.

SOŁTYSIK R. 2000 - Wpływ czynnika tektonicznego na formowanie zabagnień w strefach przedprzełomowych dolin rzecznych Gór Świętokrzyskich i ich obrzeżenia. Pr. Inst. Geogr. WSP w Kielcach, 4: 209-222. SOŁTYSIK R. 2002 - Geneza mokradeł Gór Świętokrzyskich i Niecki Nidziańskiej. Pr. Inst. Geogr. AŚ, Kielce, 9: 1-126.

STARKEL L., MICHCZYŃSKA D.J., KRAPIEC M., MARGIELEWSKI W., NALEPKA D., PAZDUR A. 2013 - Progress in the holocene chrono-climatostratigraphy of Polish territory. Geochronometria, 40 (1): $1-21$.

SZCZEPANEK K. 1971 - Kras staszowski w świetle badań paleobotanicznych. Acta Palaeobot., 12: 63-140.

SZULC J. 1983 - Geneza i klasyfikacja wapiennych osadów martwicowych. Prz. Geol., 4: 231-236.

TOBOLSKI K. 2000 - Przewodnik do oznaczania torfów i osadów jeziornych. PWN, Vademecum Geobotanicum.

TOBOLSKI K. 2003 - Torfowiska na przykładzie Ziemi Świeckiej. TPDW, Świecie.

TOBOLSKI K. 2004 - Kryterium geologiczne w badaniach zbiorników akumulacji biogenicznej. Regionalny Monitoring Środowiska Przyrodniczego, 5: 119-126.

TOWPASZ K., STACHURSKA-SWAKOŃ A. 2009 - Wystepowanie Sesleria uliginosa (Poaceae) w zbiorowiskach z rzędu Caricetalia davallianae na obszarze Niecki Nidziańskiej (Wyżyna Małopolska). Fragm. Flor. Geobot. Polonica, 16 (2): 305-316.

URBAN J. 2012 - Dziedzictwo geologiczne. [W:], Świercz A. (red.), Monografia Nadnidziańskiego Parku Krajobrazowego. Wyd. UJK w Kielcach, Kielce: $35-71$.

URBAN J. 2014 - Cechy rzeźby strukturalnej Gór Świętokrzyskich oraz południowo-wschodniej części Niecki Nidziańskiej. Prz. Geol., 62 (1): 44-50. URBAN J., CHWALIK-BOROWIEC A., KASZA A. 2015 - Warunki rozwoju i wiek krasu w gipsach Niecki Soleckiej. Biul. Państw. Inst. Geol., 462: 125-152.

URBAN J., CHWALIK-BOROWIEC A., KASZA A., GUBALA J. 2012 Jaskinie i stanowiska krasowe. [W:] Świercz A. (red.), Monografia Nadnidziańskiego Parku Krajobrazowego. Wyd. UJK w Kielcach, Kielce: $82-121$.

WADDINGTON J.M., PRICE J.S. 2000 - Effect of peatland drainage, harvesting, and restoration on atmospheric water and carbon exchange. Phys. Geogr., 5: 433-451.

WALCZOWSKI A. 1964 - Zjawiska krasowe południowo-wschodniego obrzeżenia Gór Świętokrzyskich. Ann. UMCS, sec. B, 19: 29-62.

WICIK B. 2000a - Cechy chemiczne wód gruntowych Ponidzia. Pr. Studia Geogr., 27: 81-90.

WICIK B. 2000b - Krajobrazy gipsowe Ponidzia Pińczowskiego. Pr. Studia Geogr., 27: 91-98.

WOŁEJKO L. 2002 - Soligenous wetlands of north-western Poland as an environment for endangered mire species. Acta Soc. Bot. Pol., 71 (1): 46-61.

WOŹNIAK N., ŻUREK S. 2005 - Torfowiska krasu węglanowego okolic Cieślina i Krzywopłotów oraz krasu gipsowego koło Żydowca. [W:] Partyka J. (red.), Zróżnicowanie i przemiany środowiska przyrodniczo-kulturowego Wyżyny Krakowsko-Częstochowskiej, tom 3, Ojców: 41-44.

ZIELIŃSKI A. 2013 - Rozwój jezior krasowych w Niecce Połanieckiej. Wyd. UJK w Kielcach, Kielce.

ZIUŁKIEWICZ M., OKUPNY D., FORYSIAK J., FORTUNIAK A. 2012 - Warunki funkcjonowania kopuł źródliskowych w południowej części Wzniesień Łódzkich. Czasop. Geogr., 83 (3): 175-196.

ŻUREK S. 1981 - Charakterystyka złóż surowców mineralnych - torf. [W:] Wielgomas L. (red.), Surowce mineralne województwa częstochowskiego. Wyd. Geol., Warszawa: 135-154.

ŻUREK S. 1987 - Złoża torfowe Polski na tle stref torfowych Europy. Dok. Geogr. IGiPZ PAN, 4: 1-84.

ŻUREK S. 1991/92 - The development of the peat-forming processes versus the lowland relief of Poland and hydrological change in the postglacial period. Quest. Geogr., 17/18: 95-100.

ŻUREK S. 1993 - Zmiany paleohydrologiczne w mokradłach. Prz. Geogr., 65 (1-2): 75-95.

ŻUREK S. 2000 - Przegląd badań torfowisk obszarów wyżynnych Polski ze szczególnym uwzględnieniem torfowiska Białe Ługi. Pr. Inst. Geogr. WSP w Kielcach, 4: 237-257.

ŻUREK S. 2006 - Katalog rezerwatów przyrody na torfowiskach Polski. Wyd. Akad. Świętokrzys., Kielce.

ŻUREK S., OKUPNY D. 2015 - Torfowiska regionu łódzkiego. Stud. Lim. Tel., 9: 59-69. 